\title{
Squamous cell carcinoma of rectum presenting in a man: a case report
}

A Syed Sameer ${ }^{1,2,3}$, Nidda Syeed ${ }^{1}$, Nissar A Chowdri ${ }^{3}$, Fazl Q Parray ${ }^{3}$, Mushtaq A Siddiqi $^{{ }^{*}}$

\begin{abstract}
Background: Primary squamous cell carcinomas of the colorectum are very uncommon. Until now, to the best of our knowledge, only 114 cases of squamous cell carcinoma in the colorectum exist in the reported literature. Here we report a case of squamous cell carcinoma of the rectum in the ethnic Kashmiri population in northern India.

Case Presentation: The case of a 60-year-old male patient (Asian) with a pure squamous cell carcinoma of the rectum is presented here. The patient underwent a curative surgery with concomitant chemotherapy. Two years after the initial curative resection of the tumor he is still alive.

Conclusion: The prognosis for squamous cell carcinoma of the colorectum is worse than for that of adenocarcinoma, because of the delayed diagnosis. The etiopathogenicity of squamous cell carcinoma of the colorectum is discussed. Surgical resection of the lesion seems to be the treatment of choice. Chemotherapy also helps in improvement of the prognosis.
\end{abstract}

\section{Introduction}

The occurrence of squamous cell carcinomas (SCC) in the colorectum is a rare entity representing a small fraction of colorectal malignancies, since more than $90 \%$ of colorectal diseases are adenocarcinoid tumors [1]. Very little information is available in the literature about the etiology, prognosis and optimal treatment of this malignancy [2]. Here in this study, we describe a patient with SCC of the rectum who underwent a lower anterior resection (LAR) for the possible treatment of the malignancy.

\section{Case presentation}

A 60-year-old male patient from an urban area of Kashmir (Asian) visited the Department of General Medicine of our institute with the chief complaints of severe lower-abdominal pain for the past eight months. The patient also complained of severe constipation, nausea, vomiting, anorexia, loss of appetite, abdominal cramps, incontinence of faeces and weight loss during the past four months. He experienced profuse bleeding from the rectum for the last month. Initial interviews with the

\footnotetext{
* Correspondence: vc.tmuk@gmail.com

${ }^{1}$ Department of Immunology and Molecular Medicine, Sher-I-Kashmir

Institute of Medical Sciences, Soura, Srinagar, Kashmir, 90011, India

Full list of author information is available at the end of the article
}

patient revealed that the he was a heavy smoker and frequent user of noon-chai (Salt tea), meat and pickles. On examination the patient was found to be anemic. Digital rectal examination revealed an ulcero-infiltrative lesion with restricted mobility about $4 \mathrm{~cm}$ from the anal verge on the left lateral wall. A colonoscopy confirmed the rectal examination and biopsies taken at the time of the colonoscopy revealed squamous cell carcinoma (SCC) of basal cell type in the first histopathological examination. The report was re-confirmed by a second independent pathologist. A Contrast-Enhanced Computed Tomography (CECT) of the chest, abdomen and pelvis was also done but no lesions were found in any other site than the rectum. The lesion was without any fat stranding or lymphadenopathy. Furthermore, following the provisional diagnosis, the patient was referred to the Department of General Surgery for radical treatment, where he underwent LAR of the rectum using the standard technique of mesorectal excision (Figure 1). The continuity of the gut was restored by a circular stapler for low colorectal anastomosis with formation of a colonic pouch. The colonic pouch takes over the function of rectal reservoir which is lost after excision of the middle and lower rectum. Microscopic examination of the resected lesion demonstrated a $2.5 \mathrm{~cm} \times 3 \mathrm{~cm}$ SCC tumor of the rectum infiltrating the serosa. The margins of the 


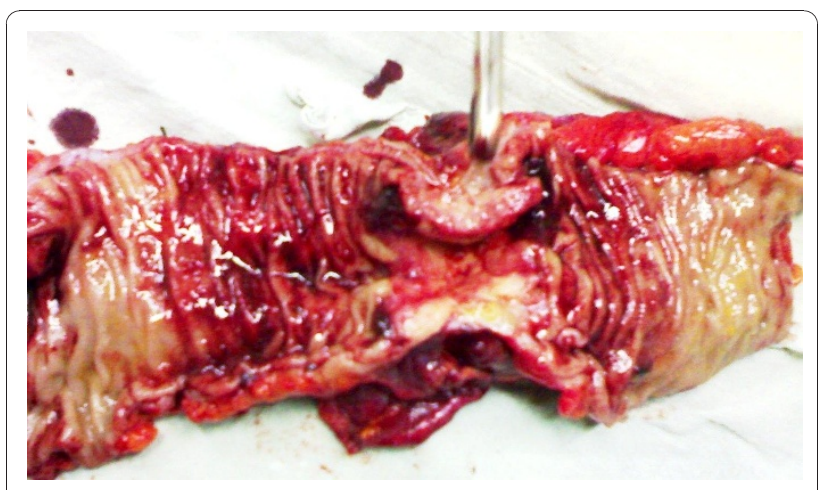

Figure 1 Image showing the inner lining of the colon with a rosette-shaped malignant tumor at the lateral wall of the rectum.

excised tissue were found to be free of the tumor. However, four regional lymph nodes were also infiltrated by the metastatic SCC cells. The liver and the rest of the organs were free of any metastasis. The slides were reviewed by a third histopathologist who reported the lesion as poorly differentiated squamous cell carcinoma. The stage of the tumor was found to be $T_{3} \mathrm{~N}_{2} \mathrm{M}_{\mathrm{o}}$. The post-operative period was uneventful. Post-operatively the patient received four cycles of chemotherapy with cisplastin and 5-fluorouracil for five days. The patient is on two years of follow-up and has not shown any evidence of recurrenceas of the present time.

\section{Discussion}

Colorectal cancer (CRC) is the third most common cause of cancer-related death in the world [3]. Almost $90 \%$ of CRC are adenocarcinomas, while the remaining $10 \%$ are made up of carcinomas, sarcomas and lymphoid tumors [1]. The occurrence of SCC in the gastrointestinal tract (GIT) is a rare phenomenon, and its occurrence in the colorectum is extremely unusual [4]. The incidence of SCC of the colorectum has been reported to be almost 0.1 to 0.25 per 1000 CRC $[4,5]$. A look into the research work and the reported cases of SCC dates back to 1907, when Herxheimer reported adenosquamous carcinoma of the cecum but it was in 1919 when the first case of pure SCC of the colon was reported by Schmidtmann [6] in a 65-year-old man [7]. It was not until 1933 that the first case involving the rectum was subsequently described by Raiford [8]. In India, Bhat et al. [9] reported the first case of pure SCC of the colon in 1993 in a 55-year-old female from the southern part of the country. Until now almost 120 cases of SCC have been reported from all over the world (See Table 1). Surprisingly, a study from Russia reported 107 cases of SCC from a single center alone [10] but there has been no such reports of high incidence of SCC in the colorectum from any other part of the world.
Before the diagnosis of primary SCC of colorectum is made, certain criteria must be fulfilled as given by Williams et al. in 1979 [11]. This criteria includes: (A) absence of evidence of squamous cell carcinoma of any other part of the body, ruling out any chance of possible metastasis from any organ to the colorectal site; (B) exclusion of any proximal extension of anal squamous cell carcinoma; (C) absence of fistulous tract lined by squamous cells; and (D) confirmation of SCC by histological analysis $[1,4,12]$. All of these criteria were fulfilled by our case.

A look at the available literature reveals that squamous cell carcinoma of the colorectum affects individuals with a mean age of 55 to 60 years Women are more frequently predisposed to SCC than men, around $66 \%$ of cases occurred in women and $34 \%$ in men. Furthermore, SCC occurs in concomitance with an advanced tumor stage (Duke's C) $[4,13]$. Since SCC of the rectum is a rare tumor, epidemiological data constituting patient demographics, risk factors and natural history are lacking in the literature. The clinical characteristics of the patients with SCC of the colorectum are similar to those with adenocarcinoma: rectal bleeding, abdominal pain, change in bowel habits and weight loss [4]. Because of the rare nature of this malignancy the prognosis for patients is difficult to establish, Comer et al. suggested a poorer prognosis for patients with colorectal SCC than adenocarcinoma $[1,4,14]$.

Almost four different pathophysiological theories regarding the origin of squamous cell carcinoma of the colorectum have been proposed in the literature so far. These can be summarized as: (A) Proliferation of uncommitted basal cells into squamous cells which undergo malignant transformation following mucosal injury [15]; (B) Ability of pluripotent stem cells to undergo spontaneous squamous differentiation [16]; (C) Squamous metaplasia of glandular epithelium resulting from chronic inflammation or irritation, secondary to inflammatory bowel disease [17], infection [18] or radiation [19]; (D) Origin from embryonal nests of ectodermal cells; and (E) Arousal of carcinomas from preexisting adenomas or adenocarcinomas $[7,20]$.

\section{Conclusion}

In conclusion, advanced colorectal SCC has a poor prognosis. Since colorectal SCC is a very rare disease, treatment selection is difficult. However, surgical resection and adjuvant chemotherapy [21] is a better approach to the treatment of colorectal SCC.

\section{Consent}

Written informed consent was obtained from the patient for publication of this case report and accompanying images. A copy of the written consent is available with 
Table 1 Reported cases of squamous cell carcinoma of the colorectum (Data available from 1933 to 2009)

\begin{tabular}{|c|c|c|c|c|c|}
\hline Study number & Study & Age & Sex & Surgery & Outcome \\
\hline 01. & Schmidtmann (1919) [6] & 65 & M & NA & Died after $1 \mathrm{~m}$ \\
\hline 02. & Raiford (1933) [8] & 43 & $\mathrm{~F}$ & NA & Died after $7 \mathrm{~m}$ \\
\hline 03. & Catell et al. (1943) [22] & 63 & M & LAR & Alive at $3.5 \mathrm{y}$ \\
\hline 04. & Wiener et al. (1962) [23] & 52 & $\mathrm{~F}$ & APR & Died at $1 \mathrm{y}$ \\
\hline 05. & Larizaden and Powell (1965) [24] & 44 & $\mathrm{~F}$ & APR & Died at $1 \mathrm{y}$ \\
\hline \multirow[t]{2}{*}{06.} & Cabrera et al. (1967) [25] & 62 & $\mathrm{~F}$ & APR & NR \\
\hline & & 50 & $\mathrm{~F}$ & & NR \\
\hline 07. & Minkowitz et al. (1967) [26] & 49 & $\mathrm{~F}$ & Proctocolectomy & Died after 5 m \\
\hline 08. & Gaston et al. (1967) [27] & 65 & M & Hemicolectomy & Alive at $2 \mathrm{y}$ \\
\hline 09. & Pemberton and Lendrum (1968) [28] & 48 & $\mathrm{~F}$ & Hemicolectomy & Alive at $2 y$ \\
\hline 10. & Birnbaum et al. (1970) [29] & 82 & M & Hemicolectomy & NR \\
\hline 11. & Corner et al. (1971) [14] & 34 & $\mathrm{~F}$ & APR & Alive at $13 \mathrm{y}$ \\
\hline 12. & Lewis et al. (1971) [30] & 61 & M & Hemicolectomy & Died after $10 \mathrm{~d}$ \\
\hline 13. & Balfour (1972) [31] & 63 & M & NA & Died after $18 \mathrm{~m}$ \\
\hline 14. & Horne and McCulloch (1978) [32] & 53 & M & Hemicolectomy & Died after $11 \mathrm{~m}$ \\
\hline 15. & Crissmann (1978) [33] & 72 & M & Colectomy & Died after $3 \mathrm{~d}$ \\
\hline 16. & Burgess et al. (1979) [34] & 43 & M & Hemicolectomy & Died after $11 \mathrm{~m}$ \\
\hline 17. & Williams et al. (1979) [11] & 45 & M & APR & Died after 9 m \\
\hline \multirow[t]{3}{*}{18.} & Lasser et al. (1980) [35] & 65 & $\mathrm{~F}$ & N/A & Alive at $3 y$ \\
\hline & & 48 & $\mathrm{~F}$ & N/A & Alive $8 \mathrm{~m}$ \\
\hline & & 54 & M & N/A & Alive $17 \mathrm{~m}$ \\
\hline 19. & Hickey and Corson (1981) [36] & 48 & $\mathrm{~F}$ & Hemicolectomy & Alive at $21 \mathrm{~m}$ \\
\hline 20. & Petrelli et al. (1981) [37] & 73 & M & Colectomy & Died after $9 \mathrm{~d}$ \\
\hline 21. & Pitella and Torres (1982) [38] & 33 & M & Ileocolic bypass & Died after $10 \mathrm{~d}$ \\
\hline \multirow[t]{2}{*}{22.} & Hey and Brandt (1982) [39] & $\mathrm{NA}$ & NA & NA & NA \\
\hline & & $\mathrm{NA}$ & NA & NA & NA \\
\hline 23. & Lyttle et al. (1983) [40] & 65 & $\mathrm{~F}$ & Hemicolectomy & Alive at $2 \mathrm{~m}$ \\
\hline \multirow[t]{5}{*}{24.} & Vezeridis et al. (1983) [41] & 56 & M & APR & Died after $10 \mathrm{~m}$ \\
\hline & & 44 & M & APR & Died after $9 \mathrm{~d}$ \\
\hline & & 61 & $\mathrm{~F}$ & & Died after 4 m \\
\hline & & 66 & $\mathrm{~F}$ & & Died after $15 \mathrm{~m}$ \\
\hline & & 62 & $\mathrm{~F}$ & APR & Died after $13 \mathrm{~m}$ \\
\hline 25. & Gould et al. (1983) [42] & 61 & M & Ileocolic bypass & Died after 3 m \\
\hline 26. & Francioni et al. (1983) [43] & NA & NA & NA & NA \\
\hline 27. & Forouhar et al. (1984) [44] & NA & NA & NA & NA \\
\hline 28. & Lafreniere et al. (1985) [13] & 60 & M & TAE & Alive at $2 \mathrm{y}$ \\
\hline \multirow[t]{2}{*}{29.} & Balsano et al. (1985) [45] & 65 & M & Hemicolectomy & NA \\
\hline & & 58 & M & Hemicolectomy & NA \\
\hline 30. & Chulia et al. (1986) [46] & NA & NA & NA & NA \\
\hline 31. & Weidner and Zekan, (1986) [47] & 73 & M & NA & Died after 4 y \\
\hline 32. & Piggott and Williams (1987) [48] & 60 & $\mathrm{~F}$ & APR & Alive at $13 \mathrm{~m}$ \\
\hline 33. & Woods et al. (1987) [49] & 57 & $\mathrm{~F}$ & APR & Died after 3 m \\
\hline 34. & Shao et al. (1987) [50] & NA & NA & NA & NA \\
\hline \multirow[t]{5}{*}{35.} & Prener et al. (1988) [51] & 43 & $\mathrm{~F}$ & APR & Died after 1 y \\
\hline & & 77 & $\mathrm{~F}$ & Polypectomy & Died after 3 y \\
\hline & & 55 & $\mathrm{~F}$ & APR & Alive at $3 y$ \\
\hline & & 55 & M & APR & Died after 3 m \\
\hline & & 53 & $M$ & APR & Died after 1 y \\
\hline
\end{tabular}


Table 1 Reported cases of squamous cell carcinoma of the colorectum (Data available from 1933 to 2009) (Continued)

\begin{tabular}{|c|c|c|c|c|c|}
\hline 36. & Lundquest et al. (1988) [52] & NA & NA & NA & NA \\
\hline 37. & Wyatt (1991) [53] & 71 & M & NA & Alive at $1 \mathrm{y}$ \\
\hline \multirow[t]{2}{*}{38.} & Schneider et al. (1992) [54] & 44 & M & & NA \\
\hline & & 69 & $\mathrm{~F}$ & TAE & Alive at $3 \mathrm{y}$ \\
\hline 39. & Betancourt et al. (1992) [55] & NA & NA & NA & NA \\
\hline 40. & Vignale et al. (1993) [56] & 69 & M & NA & NA \\
\hline 41. & Yoshida et al. (1994) [57] & 51 & M & Hemicolectomy & Died after $39 \mathrm{~d}$ \\
\hline 42. & Vraux et al. (1994) [58] & NA & NA & Chemotherapy & Died after $5 \mathrm{y}$ \\
\hline 43. & Alekseev et al. (1994) [59] & NA & NA & NA & NA \\
\hline \multirow[t]{2}{*}{44.} & Petrelli et al. (1996) [60] & 62 & M & APR & NA \\
\hline & & 41 & $\mathrm{~F}$ & Colectomy & NA \\
\hline 45. & Martinez-Gonzalez et al. (1996) [61] & 40 & M & LAR & Alive at $18 \mathrm{~m}$ \\
\hline \multirow[t]{2}{*}{46.} & Juturi et al. (1998) [62] & 61 & $\mathrm{~F}$ & Hemicolectomy & Alive at $18 \mathrm{y}$ \\
\hline & & 61 & M & Hemicolectomy & Died after $15 \mathrm{~m}$ \\
\hline 47. & Kim et al. (2001) [63] & 41 & $\mathrm{~F}$ & LAR & Died after $4 \mathrm{~m}$ \\
\hline 48. & Copur et al. (2001) [64] & 54 & M & $\mathrm{APR}+\mathrm{CT}$ & NA \\
\hline 49. & Sotlar et al. (2001) [65] & 87 & M & LAR & Died after $20 \mathrm{~m}$ \\
\hline 50. & Frizelle et al. (2001) [66] & 9 cases & & & \\
\hline \multirow[t]{6}{*}{51.} & Gelas et al. (2002) [2] & 47 & $\mathrm{~F}$ & $\mathrm{APR}+\mathrm{CT}$ & Alive at $16 \mathrm{y}$ \\
\hline & & 63 & M & $\mathrm{APR}+\mathrm{CT}$ & Died after $14 \mathrm{~m}$ \\
\hline & & 70 & $\mathrm{~F}$ & APR & Died after $18 \mathrm{~m}$ \\
\hline & & 93 & M & & Died after $4 \mathrm{~m}$ \\
\hline & & 45 & $\mathrm{~F}$ & LAR & Alive at $6 \mathrm{~m}$ \\
\hline & & 43 & $\mathrm{~F}$ & LAR & Alive at $2 \mathrm{y}$ \\
\hline 52. & Bhat et al. (2003) [9] & 55 & $\mathrm{~F}$ & Hemicolectomy & NA \\
\hline 53 & Kim, 2005 [67] & 71 & M & & NA \\
\hline 54. & Anagnostopoulos et al. (2005) [7] & 75 & M & APR & Alive at $14 \mathrm{~m}$ \\
\hline 55. & Lam et al. (2006) [68] & 44 & $\mathrm{~F}$ & LAR & NA \\
\hline 56. & Theodosopoulos et al. (2006) [21] & 39 & $\mathrm{~F}$ & APR & Alive at $18 \mathrm{~m}$ \\
\hline 57. & Ambrosini-Spaltro et al. (2006) [69] & 81 & M & Hemicolectomy & Alive at $2 \mathrm{y}$ \\
\hline 58. & Pikarsky et al. (2006) [70] & 57 & $\mathrm{~F}$ & & Alive at $7 \mathrm{yr}$ \\
\hline 59. & Nahas et al. (2007) [5] & 58 & $\mathrm{~F} 10 / \mathrm{M} 2$ & & Alive at $2.6 \mathrm{yr}$ \\
\hline 60. & Miyamoto (2007) [1] & 89 & M & Colectomy & Died after $3 \mathrm{~m}$ \\
\hline 61. & Cheng et al. (2007) [71] & 51 & $\mathrm{~F}$ & Proctocolectomy & NA \\
\hline \multirow[t]{2}{*}{62.} & Kong et al. (2007) [72] & 48 & $\mathrm{~F}$ & TAE & Alive at $3 y$ \\
\hline & & 53 & $\mathrm{~F}$ & NA & \\
\hline \multirow[t]{7}{*}{63.} & Clark et al. (2008) [73] & 75 & M & & Alive at $20 \mathrm{~m}$ \\
\hline & & 71 & $\mathrm{~F}$ & & Alive at $31 \mathrm{~m}$ \\
\hline & & 42 & $\mathrm{~F}$ & & Alive at $13 \mathrm{~m}$ \\
\hline & & 70 & M & & Alive at $14 \mathrm{~m}$ \\
\hline & & 55 & $\mathrm{~F}$ & LAR & Alive at $19 \mathrm{~m}$ \\
\hline & & 45 & $\mathrm{~F}$ & & Alive at $23 \mathrm{~m}$ \\
\hline & & 71 & $\mathrm{~F}$ & & Alive at $5 \mathrm{~m}$ \\
\hline
\end{tabular}




\section{Table 1 Reported cases of squamous cell carcinoma of the colorectum (Data available from 1933 to 2009) (Continued)}

\begin{tabular}{|c|c|c|c|c|c|}
\hline \multirow[t]{6}{*}{64.} & Rasheed et al. (2009) [74] & 55 & $\mathrm{~F}$ & & Alive at $11 \mathrm{y}$ \\
\hline & & 50 & M & & Alive at $7 \mathrm{y}$ \\
\hline & & 69 & $\mathrm{~F}$ & & Alive at $4 \mathrm{y}$ \\
\hline & & 61 & M & APR & Alive at $4 \mathrm{y}$ \\
\hline & & 58 & M & APR & Alive at 2 y \\
\hline & & 41 & $\mathrm{~F}$ & & Alive at 2 y \\
\hline 65. & Our Case & 60 & $M$ & LAR & Alive at $15 \mathrm{~m}$ \\
\hline
\end{tabular}

NA: not available; F: female; M: male; LAR: low anterior resection; APR: abdominoperineal resection; TAE:transanal excision; y: years; m: months and d: days

the corresponding author of this manuscript and is accessible for review by the Editor-in-Chief of this journal

\section{Acknowledgements}

The authors gratefully acknowledge the Sher-I-Kashmir Institute of Medical Sciences, Kashmir for providing funds for this research work. The authors also gratefully acknowledge the technical staff, especially Miss Roohi and Mr. Reyaz of the Department of General Surgery for helping in the procurement of tumor tissue samples from the Operation Theater. We also thank the anonymous pathologists of the Department of Pathology for the histopathological assessment of the tumor tissues.

\section{Author details}

'Department of Immunology and Molecular Medicine, Sher-I-Kashmir Institute of Medical Sciences, Soura, Srinagar, Kashmir, 90011, India. ${ }^{2}$ Department of Clinical Biochemistry, Sher-I-Kashmir Institute of Medical Sciences, Soura, Srinagar, Kashmir, 190011, India. ${ }^{3}$ Department of General Surgery, Sher-I-Kashmir Institute of Medical Sciences, Soura, Srinagar, Kashmir, 190011, India.

\section{Authors' contributions}

ASS conceived and designed the study and wrote the manuscript. NS suggested the necessary changes and copyedited the manuscript. NAC and FQP procured and provided the tumor samples for the study. MAS coordinated the study and revised the manuscript. All authors read and approved the final manuscript.

\section{Competing interests}

The authors declare that they have no competing interests.

Received: 8 December 2009 Accepted: 30 November 2010 Published: 30 November 2010

\section{References}

1. Miyamotoa H, Nishiokaa M, Kuritaa N, Hondaa J, Yoshikawaa K, Higashijimaa J, Miyatania T, Bandoub Y, Shimadaa M: Squamous cell carcinoma of the descending colon: report of a case and literature review. Case Rep Gastroenterol 2007, 1:77-83.

2. Gelas T, Peyrat P, Francois Y, Gerard JP, Baulieux J, Gilly FN, Vignal J, Glehen O: Primary squamous-cell carcinoma of the rectum: report of six cases and review of the literature. Dis Colon Rectum 2002, 45:1535-1540.

3. Sameer AS, Rehman S, Pandith AA, Syeed N, Shah ZA, Chowdhri NA, Wani KA, Siddiqi MA: Molecular gate keepers succumb to gene aberrations in colorectal cancer in Kashmiri population, revealing a high incidence area. Saudi J Gastroenterol 2009, 15:244-252.

4. Dyson T, Draganov PV: Squamous cell cancer of the rectum. World J Gastroenterol 2009, 15:4380-4386.

5. Nahas CS, Shia J, Joseph R, Schrag D, Minsky BD, Weiser MR, Guillem JG, Paty PB, Klimstra DS, Tang LH, Wong WD, Temple LK: Squamous-cell carcinoma of the rectum: a rare but curable tumor. Dis Colon Rectum 2007, 50:1393-1400.

6. Schmidtmann M: Zur Kenntnis seltener Krebsformen. Virchow Arch (A) 1919, 226:100-118.
7. Anagnostopoulos G, Sakorafas GH, Kostopoulos P, Grigoriadis K, Pavlakis G Margantinis G, Vugiouklakis D, Arvanitidis D: Squamous cell carcinoma of the rectum: a case report and review of the literature. Eur J Cancer Care Engl 2005, 14:70-74.

8. Raiford TS: Epitheliomata of the lower rectum and anus. Surg Gynecol Obstet 1933, 57:21-35.

9. Bhat S, Pai M, Premnath RP: Primary squamous cell carcinoma of caecum. Indian J Cancer 2003, 40:118-119.

10. Mel'nikov RA, Goshchitskil LG, Kovalev VK: Clinical manifestations of squamous cell carcinoma of the rectum. Vopr Onkol 1984, 30:76-83.

11. Williams GT, Blackshaw AJ, Morson BC: Squamous carcinoma of the colorectum and its genesis. J Pathol 1979, 129:139-147.

12. Carroll D, Rajesh PB: Colonic metastases from primary squamous cell carcinoma of the lung. Eur J Cardiothorac Surg 2001, 19:719-720.

13. Lafreniere R, Ketcham AS: Primary squamous carcinoma of the rectum. Report of a case and review of the literature. Dis Colon Rectum 1985, 28:967-972.

14. Comer TP, Beahrs OH, Dockerty MB: Primary squamous cell carcinoma and adenoacanthoma of the colon. Cancer 1971, 58:111-117.

15. Michelassi F, Montag AG, Block GE: Adenosquamous-cell carcinoma in ulcerative colitis. Report of a case. Dis Colon Rectum. 1988, 31:323-326.

16. Ouban A, Nawab RA, Coppola D: Diagnostic and pathogenetic implications of colorectal carcinomas with multidirectional differentiation: a report of 4 cases. Clin Colorectal Cancer 2002, 1:243-248.

17. Fu K, Tsujinaka Y, Hamahata Y, Matsuo K, Tsutsumi O: Squamous metaplasia of the rectum associated with ulcerative colitis diagnosed using narrow-band imaging. Endoscopy 2008, 40:E45-E46.

18. Audeau A, Han HW, Johnston MJ, Whitehead MW, Frizelle FA: Does human papilloma virus have a role in squamous cell carcinoma of the colon and upper rectum? Eur J Surg Oncol 2002, 28:657-660.

19. Yurdakul G, de Reijke TM, Blank LE, Rauws EA: Rectal squamous cell carcinoma 11 years after brachytherapy for carcinoma of the prostate. J Urol 2003, 169:280.

20. Jaworski RC, Biankin SA, Baird PJ: Squamous cell carcinoma in situ arising in inflammatory cloacogenic polyps: report of two cases with PCR analysis for HPV DNA. Pathology 2001, 33:312-314.

21. Theodosopoulos TK, Marinis AD, Dafnios NA, Vassiliou JG, Samanides LD, Carvounis EE, Smyrniotis VE: Aggressive treatment of metastatic squamous cell carcinoma of the rectum to the liver: a case report and a brief review of the literature. World Journal of Surgical Oncology 2006, 4:49.

22. Catell RB, Williams AG: Epidermoid carcinoma of the anus and rectum. Arch Surg 1943, 46:336-349.

23. Wiener MF, Polayes SH, Yidi R: Squamous carcinoma with schistosomiasis of the colon. Am J Gastroent 1962, 37:48-54.

24. Larizaden R, Powell DE: Neoplastic change in a duplicated colon. Br J Surg 1965, 52:666-668

25. Cabrera A, Pickren JW: Squamous metaplasia and squamous-cell carcinoma of the rectosigmoid. Dis Colon Rectum 1967, 10:288-297.

26. Minkowitz S: Primary squamous cell carcinoma of the rectosigmoid portion of the colon. Arch Pathol 1967, 84:77-80.

27. Gaston EA: Squamous-cell carcinoma of the colon and rectum: report of a case. Dis Colon Rectum 1967, 10:435-434.

28. Pemberton M, Lendrum J: Squamous-cell carcinoma of the caecum following ovarian adenocarcinoma. Br J Surg 1968, 55:273-276.

29. Birnbaum W: Squamous cell carcinoma and adenoacanthoma of the colon. JAMA 1970, 212:1511-1513. 
30. Lewis PL, Harrer WW, Sencindiver PV: Primary squamous-cell carcinoma of the cecum: report of a case. Dis Colon Rectum 1971, 14:213-217.

31. Balfour TW: Does squamous carcinoma of the colon exist? Br J Surg 1972, 59:410-412.

32. Horne BD, McCulloch CF: Squamous cell carcinoma of the cecum: a case report. Cancer 1978, 42:1879-1882.

33. Crissman JD: Adenosquamous and squamous cell carcinoma of the colon. Am J Surg Pathol 1978, 2:47-54.

34. Burgess PA, Lupton EW, Talbot IC: Squamous-cell carcinoma of the proximal colon: report of a case and review of the literature. Dis Colon Rectum 1979, 22:241244.

35. Lasser P, Elias D, Eschwege F: A propos de 3 cas d'epitheliomas epidermoides du rectum. J Chir 1980, 117:377-380.

36. Hickey WF, Corson JM: Squamous cell carcinoma arising in a duplication of the colon: case report and literature review of squamous cell carcinoma of the colon and of malignancy complicating colonic duplication. Cancer 1981, 47:602-609.

37. Petrelli M, Tetangco E, Reid JD: Carcinoma of the colon with undifferentiated, carcinoid, and squamous cell features. Am J Clin Pathol 1981, 75:581-584.

38. Pittella JE, Torres AV: : Primary squamous-cell carcinoma of the cecum and ascending colon: report of a case and review of the literature. Dis Colon Rectum 1982, 25:483-487.

39. Hey A, Brandt G: [A pure squamous cell carcinoma of the large intestine. Report of 3 personal observations and a literature review]. Pathologe 1982, 3:359-364.

40. Lyttle JA: Primary squamous carcinoma of the proximal large bowel. Report of a case and review of the literature. Dis Colon Rectum 1983, 26:279-282.

41. Vezeridis MP, Herrera LO, Lopez GE, Ledesma EJ, Mittleman A: Squamouscell carcinoma of the colon and rectum. Dis Colon Rectum 1983, 26:188-191.

42. Gould L, Shah JM, Khedekar RR, Burns WA: Squamous cell carcinoma of the splenic flexure of the colon. Dig Dis Sci 1983, 28:918-922.

43. Francioni G, Canuti S, Cardelli A, Montesi M: [Epidermoid carcinoma of the colon. Clinical case of double recto-sigmoid basalioma]. Minerva Dietol Gastroenterol 1983, 29:33-38.

44. Forouhar F: Neoplastic colonic polyp with extensive squamous metaplasia. Case report. Tumori 1984, 70:99-103.

45. Balsano NA: Squamous cell carcinoma of the cecum. Arch Surg 1985 120:1176-1177.

46. Chulia F, Camps C, Rodriguez A, Medina E, Tuset J: Epidermoid carcinoma of the colon. Description of a lesion located in the hepatic flexure. Dis Colon Rectum 1986, 29:665-667.

47. Weidner N, Zekan P: Carcinosarcoma of the colon - Report of a unique case with light and immuoistochemical studies. Cancer 1986, 58:1126-1130.

48. Piggott JP, Williams GB: Primary squamous cell carcinoma of the colorectum: case report and literature review of a rare entity. J Surg Oncol 1987, 35:117-119.

49. Woods WG: Squamous cell carcinoma of the rectum arising in an area of squamous metaplasia. Eur J Surg Oncol 1987, 13:455-458.

50. Shao YF, Pan GL, Zhou CN, Yu HT: : [Squamous cell carcinoma of the ascending colon-a case report and review of literature]. Zhonghua Zhong Liu Za Zhi 1987, 9:315-316.

51. Prener A, Nielsen K: Primary squamous cell carcinoma of the rectum in Denmark. APMIS 1988, 96:839-844.

52. Lundquest DE, Marcus JN, Thorson AG, Massop D: : Primary squamous cell carcinoma of the colon arising in a villous adenoma. Hum Pathol 1988, 19:362-364.

53. Wyatt MG, Clarke TJ, Teasdale C: Primary squamous cell carcinoma of the caecum. Eur J Surg Oncol 1991, 17:392-394.

54. Schneider TA, Birkett DH, Vernava AM: Primary adenosquamous and squamous cell carcinoma of the colon and rectum. Int J Colorectal Dis 1992, 7:144-147.

55. Betancourt C, Berríos G, Peña E: : [Squamous cell carcinoma of the colon A case report]. G EN 1992, 46:331-335.

56. Vignale R, Espasandin J, Deneo H, Gonzalez V: : Halo seborrheic keratosis associated with colon carcinoma. Int J Dermatol 1993, 32:846.
57. Yoshida J, Tohma H, Nagata T, Okuzono Y, Takahashi M: Squamous cell carcinoma of the splenic flexure of the colon: report of a case. Surg Today 1994, 24:75-79.

58. Vraux H, Kartheuser A, Haot J, Humblet Y, Detry R, Dive C, Kestens PJ: Primary squamous-cell carcinoma of the colon: a case report. Acta Chir Belg 1994, 94:318-320.

59. Alekseev VS, Bolkov VP, Pavlov NV, Karyshev PB: [Squamous cell cancer of the colon with inflammation]. Khirurgiia Mosk; 1994:12:58.

60. Petrelli NJ, Valle AA, Weber TK, Rodriguez-Bigas M: Adenosquamous adenocarcinoma of the colon and rectum. Dis Colon Rectum 1996, 39:1265-1268

61. Martinez-Gonzalez MD, Takahashi T, Leon-Rodriguez E, GamboaDominguez A, Lome C, Garcia-Blanco MC, Bezaury P, Moran MA: Case report of primary squamous carcinoma of the rectum. Rev Invest Clin 1996, 48:453-456.

62. Juturi JV, Francis B, Koontz PW, Wilkes JD: Squamous-cell carcinoma of the colon responsive to combination chemotherapy: report of two cases and review of the literature. Dis Colon Rectum 1999, 42:102-109.

63. Kim JH, Moon WS, Kang MJ, Park MJ, Lee DG: Sarcomatoid carcinoma of the colon: a case report. J Korean. Med Sci 2001, 16:657-660.

64. Copur S, Ledakis P, Novinski D, Mleczko KL, Frankforter S, Bolton M, Fruehling RM, VanWie E, Norvell M, Muhvic J: Squamous cell carcinoma of the colon with an elevated serum squamous cell carcinoma antigen responding to combination chemotherapy. Clin Colorectal Cancer 2001, 1:55-58.

65. Sotlar K, Köveker G, Aepinus C, Selinka HC, Kandolf R, Bültmann B: Human papillomavirus type 16-associated primary squamous cell carcinoma of the rectum. Gastroenterology 2001, 120:988-994.

66. Frizelle FA, Hobday KS, Batts KP, Nelson H: Adenosquamous and squamous carcinoma of the colon and upper rectum: a clinical and histopathologic study. Dis Colon Rectum 2001, 44:341-346.

67. Kim N, Luchs JS, Halpern D, Davis E, Donovan V, Weston SR, Katz DS: Radiology-pathology conference: carcinosarcoma of the colon. J Clin Imag 2005, 29:259-262.

68. Lam AK, Ho YH: Primary squamous cell carcinoma of the rectum in a patient on immunosuppressive therapy. Pathology 2006, 38:74-76.

69. Ambrosini-Spaltro A, Salvi F, Betts CM, Frezza GP, Piemontese A, Del Prete $\mathrm{P}$, Baldoni C, Foschini MP, Viale G: Oncocytic modifications in rectal adenocarcinomas after radio and chemotherapy. Virchows Arch 2006, 448:442-448.

70. Pikarsky AJ, Belin B, Efron J, Woodhouse S, Weiss EG, Wexner SD, Nogueras JJ: Squamous cell carcinoma of the rectum in ulcerative colitis: case report and review of the literature. Int J Colorectal Dis 2007, 22:445-447.

71. Cheng H, Sitrin MD, Satchidanand SK, Novak JM: Colonic squamous cell carcinoma in ulcerative colitis: Report of a case and review of the literature. Can J Gastroenterol 2007, 21:47-50.

72. Kong CS, Welton ML, Longacre TA: Role of human papillomavirus in squamous cell metaplasia-dysplasiacarcinoma of the rectum. Am J Surg Pathol 2007, 31:919-925.

73. Clark J, Cleator S, Goldin R, Lowdell C, Darzi A, Ziprin P: Treatment of primary rectal squamous cell carcinoma by primary chemoradiotherapy: should surgery still be considered a standard of care? Eur J Cancer 2008, 44:2340-2343.

74. Rasheed S, Yap T, Zia A, McDonald PJ, Glynne-Jones R: Chemoradiotherapy: an alternative to surgery for squamous cell carcinoma of the rectum-report of six patients and literature review. Colorectal Dis 2009, 11:191-197

doi:10.1186/1752-1947-4-392

Cite this article as: Sameer et al: Squamous cell carcinoma of rectum presenting in a man: a case report. Journal of Medical Case Reports 2010 4:392. 